\title{
Diversity of Salt Tolerance During Germination in Medicago cil- iaris (L.) and Medicago polymorpha (L.)
}

\author{
Chérifi Khalil ${ }^{*}$, ElHoussein Boufous², and Abdelhamid El Mousadik' \\ ' Laboratory of Biotechnology and Valorization of Natural Resources, Faculty of sciences, lbn Zohr University, \\ P. O. Box 8106, 8000 Agadir, Morocco; ${ }^{2}$ Department of Biochemistry and Microbiology, Université Laval, \\ Québec city (Québec), Canada
}

Received: August 7, 2011 / Accepted: November 22, 2011

\begin{abstract}
Variability of salt tolerance in eight wild populations of two annual Medicago species (Medicago ciliaris and Medicago polymorpha) was evaluated at germination stage using tree treatments of salinity: 50,100 and $150 \mathrm{mM}$ of $\mathrm{NaCl}$. Results showed that germination is clearly affected by high salt stress; their germination rate doesn't exceed $7 \%$ at $150 \mathrm{mM}$. The greatest variability in tolerance was observed at moderate salt stress $(50 \mathrm{mM}$ of $\mathrm{NaCl}$ ) and the decrease in germination seems to be more accentuated in Medicago polymorpha than Medicago ciliaris. Whereas, the Tunisian population of Medicago ciliaris was the best tolerant in all ecotypes studied in this work. This population prospected on soils affected by salinity, exhibits a particular adaptability to salt environment, at least at this stage in the life cycle. This intra-specific variation in salt folerance may be used to select genotypes particularly suitable for cultivation on lands relatively affected by salinity. On the other hand, when ungerminated seeds from $\mathrm{NaCl}$ treatments were transferred to distilled water, they recovered largely their germination at all the populations studied after only 2 days. This, indicate that the germination inhibition was related to osmotic stress rather than ion toxicity. In addition, seed germination in all populations tended to be extremely rapid than that observed in distilled water which indicate that this pretreatment raises dormancy.

Key words: Salt tolerance, Intra-specific Variation, Germination recovery, Annual Medicago, osmotic stress.
\end{abstract}

* Corresponding author: Kcherifi@yahoo.com

\section{Introduction}

In arid and semi-arid regions, soil salinity, often associated with the water constraint, constitutes one of the main environmental problems for development and crop productivity of plants. It causes reduction of cultivable area and combined with other factors, presents a serious threat to food stability in these areas (Kinet et al., 1998; Ashraf and Foolad, 2007). In the North Africa and the Middle East, 15 million hectares of arable lands are affected by salinity and this area is in continuous progression (Le Houérou, 1986; Lahmar and Ruellan, 2007). These vast regions are not exploited, except when they occasionally constitute a poor pasture land or irrigated domain with low yield. In Morocco, they correspond especially to arid and semi-arid regions where $80 \%$ of available water for irrigation contains salinity higher or equal to $5 \mathrm{~g} \mathrm{~L}^{-1}$ (Choukr-allah, 1991). In these marginal regions, plant biodiversity is reduced considerably and soil is dramatically degraded. Thus, a great number of plant species are threatened with disappearance and emergency measures must be taken to preserve the $M$. In front of this problem, the selection of salt tolerant species and varieties remains the best economic approach for exploitation and rehabilitation of saltaffected regions (Shannon, 1985; Alonso et al., 1999; Ghoulam et al., 2001). The effectiveness of such approach depends on the availability of genetic variation in relation with salt tolerance and its exploitation by screening and selection of the powerful plants under saline stress (Al-Khatib et al., 1992; Ali et al., 2007; Hussain et al., 2010). For many crop species, intraspecific variability for salt tolerance have been identified among cultivars and wild species (Al-Khatib et al., 1992; Chaudhary et 
al., 1996; Foolad, 1999; Mezni et al., 2002; Malcolm et al., 2003; Sibole et al., 2003; Raccuia et al., 2004; Hamrouni et al., 2008; Correia et al., 2010) . These rustic resources are well adapted and constitute a potential reservoir useful to provide interesting materials in order to diversify and increase the productivity, particularly in pasture land affected by salinity. The majority of plant species of agronomic interest are arranged in glycophytes group, they present a large variation in salt tolerance behavior. The most sensitive species undergo growth reduction, often considerable at low salt concentrations. On the other hand, the tolerant species react to the harmful effect of salt by accumulation of toxic ions and a better mobilization of active organic compounds like glycine-betain and proline witch enable to avoid withering and to limit growth reduction of plants (Khedr et al., 2003; Vinocur and Altman, 2005; Ashraf and Foolad, 2007). In this work, we focus on two annual species of Medicago chosen for their forage quality and their capacity to improve nitrogenation of salted land: Medicago ciliaris (L.) and Medicago polymorpha (L.). They grow naturally in a semi-arid to arid superior bioclimatic stages in Morocco. These species, classed as glycophytes, may be observed on relatively saline soils in association with halophytes (Abdelly et al., 2006; Merabet et al., 2006; Barrett-Lennard and Setter, 2010). In these areas, the halophytic species do not represent a good pastoral resource, at least for livestock because they are loaded with salt, which accounts for 15 to $30 \%$ of dry matter. On the other hand, medics contain ten times fewer of $\mathrm{NaCl}$ (Abdelly et al., 1995). Annual species of Medicago are very appreciated and supported by the halophytes, which contribute periodically to the maintenance of low saline soil. However, their productivity can be reduced by $40 \%$ in salt concentration to $12 \mathrm{~g} \mathrm{~L}^{-1}$ (Levigneron et al., 1995). The use of these species for rehabilitation and exploitation of lands affected by salinity can contribute to install, between the halophytes, an interesting potential of grassland for exploiting this ecosystem like grazing area. Successful establishment of plants often depends on germination success, especially those that grow in salt affected areas. Seeds of various halophytic or glycophytic species, show an important variability with their ability to germinate in various salt concentrations (Ben Naceur et al., 2001; Mensah et al., 2006; Rogers et al., 2008). Their germination decreases with the increasing salinity and in natural environment, they generally germinate in the period which follows strong precipitations, thus allowing a reduction of soil salinity level (Al-Khateeb, 2006; Gorai and Neffati, 2007). Usually, germination capacity under high salinity conditions is not always correlated with the ability of plant to grow under salt stress because both are controlled by different mechanisms (Malcolm et al., 2003; Yamaguchi and Blumwald, 2005). Although it's possible to find genotypes with similar tolerance at germination and during vegetative growth (Flowers, 2004; Dai et al., 2009). On top of that, in arid and semi-arid areas, high temperatures are added to salt effect and affect dramatically seed germination capacity. It decreases considerably when temperatures remain lower than $18^{\circ} \mathrm{C}$ and when they exceed $25^{\circ} \mathrm{C}$ (Itamar and Ray, 1988; El-Keblawy and Al-Shamsi, 2008). The aim of the present study was to assess salt tolerance variability at germination stage of Medicago ciliaris and Medicago polymorpha, until now not estimated, in order to explore opportunities for selection and breeding salt tolerant genotypes. The study will also assess to determine if salt stress is induced by osmotic constraints or toxic effect of $\mathrm{NaCl}$.

\section{Materials and Methods}

\section{Plant Material}

Seven wild populations prospected in the south-west of Morocco and one Tunisian population were studied: four populations of Medicago ciliaris and four populations of Medicago polymorpha. For each species, pods representative of each population were collected randomly on diverse regions reputed to be more or less affected by salinity. The four ecotypes of Medicago polymorpha are originating from the areas of Marrakech (Pmark), Taroudant (Ptar), Chtouka Ait Baha (Pchka) and Massa (Pmasa). Those of Medicago ciliaris are collected near Marrakech (Cmark), Taza (Ctaz), Tétouan (Ctéto) and Tunisia (Ctuni). This last population was collected near sabkha of Bouflcha city and chooses in this work like control population for salt tolerance estimation.

\section{Germination}

Seeds from different pods (for limiting parental effect) were manually scarified and sterilized with $0.5 \%$ Sodium Hypochlorite solution $(\mathrm{NaOCl})$ for $10 \mathrm{~min}$, then rinsed with sterile distilled water several times, and briefly blotted on filter paper. Tree replicates of 30 seeds from each accession were placed in plastic Petri dishes ( $90 \mathrm{~mm}$ diameter) on filter paper wetted with distilled water (control) and three salinity concentrations $(50,100$ and $150 \mathrm{mM} \mathrm{NaCl}$ ). Petri dishes were randomized in a precision incubator and maintained in the dark at $20 \pm 0.5^{\circ} \mathrm{C}$. Seeds were considered to have germinated when their radicle reached at least $3 \mathrm{~mm}$ long. Germination response was recorded daily for 10 days. To test germination recovery performance after exposure of seeds to $\mathrm{NaCl}$ solutions, ungerminated seeds were transferred to distilled water and incubated for 3 days. Germination was estimated using both the Final germination percentage (FGP) and germination rate index (GRI):

$\mathrm{FGP}=(\mathrm{Nt} / \mathrm{N}) \times 100$ were $\mathrm{Nt}$ is the total number of germinated seeds and $N$ is the number of tested seeds.

$G R I=(G 1 / 1)+(G 2 / 2)+\ldots+(G x / x)$ where $G$ is the germination percentage at each day after sowing, and $1,2, \ldots$, $x$ represents the corresponding day of germination. The value of GRI was higher when seeds germinated earlier. This parameter described by Esechie (1994) and Weng and Hsu (2006) is a measure of seedling vigor and should involve not only germination but emergence characteristics.

\section{Statistical Analysis}

All values expressed as a percentage were arcsin square root transformed before performing statistical analysis to nor- 
malize the data and to homogenize the variance (Turkington et al., 2002). These measures were submitted to a two ways analysis of variance (ANOVA) with populations and salinity treatments as factors followed by a Student-Newman-Keuls post hoc test. A difference was considered to be statistically significant when $P<0.05$. All statistical analysis were performed with Statistica software Version 6.1 for Windows (Statsoft, 2001).

\section{Results}

\section{Effect of Salinity on Seed Germination}

For the tow species, ANOVA test showed significant differences for both population and $\mathrm{NaCl}$ concentration regarding seed germination $(P<0.01$ ) (Table 1 and 2 ). The salinity $x$ population interaction, which indicate a differential effect of salinity between populations, was highly significant at $M$. ciliaris, but no significant in $M$. polymorpha ecotypes $(F=1.446, p<0.210)$ for final germination percentage (Table 1). However, for rate index this interaction is highly significant for the two species (Table 2).

Mean comparison at different salinity levels indicated that increase of salinity causes a decrease in seed germination percentage, which was higher in distilled water than in any $\mathrm{NaCl}$ concentration. In all populations, salt concentrations delayed the beginning of germination (Fig. 1) and reduced the final germi- nation percentages (Fig. 2).

The greatest variability in tolerance was observed at $50 \mathrm{mM}$ of $\mathrm{NaCl}$. At this saline stress, the decrease in germination seems to be less accentuated in $M$. ciliaris than $M$. polymorpha populations. However, in this last group, the decreasing was significantly different among populations: Pchka, which overlap with Medicago ciliaris genotypes, showed the highest final germination percentage $(F G P=50 \%$ ) and (GRI $=8.58 \%)$. Whereas, the less tolerant populations, especially Ptar showed FGP and GRI values respectively $20 \%$ and $3.22 \%$.

In M. ciliaris, which represent the most tolerant genotypes, significant differences were also recorded: Ctuni population originated from saline soil (Tunisia) showed very high final germination percentage (FGP $=100 \%$ ) and revealed an earlier seed germination (GRI $=48.67 \%$ ). The Cmark population can be regarded as moderately tolerant to salt stress (FGP and GRI closed, respectively, to $76.67 \%$ and $35.90 \%$ ). The remaining populations Ctéto and Ctaz were the most sensitive genotypes to salinity and form a homogeneous group with the most tolerant genotype of $M$. polymorpha (Pchka).

At $100 \mathrm{mM}$, seed germination was more affected by salinity. However, the decreasing was also significantly different among populations. M. ciliaris seems to be more tolerant than M. polymorpha populations that react in the same way to this concentration (FGP never fell above 10\%). Whereas, Ctuni was the best

Table 1. Variance analysis for final germination percentage of Medicago ciliaris and Medicago polymorpha populations.

\begin{tabular}{|c|c|c|c|c|c|c|c|c|}
\hline \multirow[b]{2}{*}{$\begin{array}{l}\text { Source of } \\
\text { variation }\end{array}$} & \multicolumn{4}{|c|}{ Medicago ciliaris } & \multicolumn{4}{|c|}{ Medicago polymorpha } \\
\hline & d. f. & $M C$ & $\mathrm{~F}$ & $p$ & d.f. & $M C$ & $\mathrm{~F}$ & $p$ \\
\hline $\mathrm{NaCl}$ & 3 & 4.420 & 406.799 & 0.000 & 3 & 5.395 & 546.404 & 0.000 \\
\hline Population & 3 & 0.182 & 16.775 & 0.000 & 3 & 0.037 & 3.775 & 0.019 \\
\hline $\begin{array}{l}\mathrm{NaCl} x \\
\text { Population }\end{array}$ & 9 & 0.088 & 8.120 & 0.000 & 9 & 0.014 & 1.446 & 0.210 \\
\hline Error & 32 & 0.010 & & & 32 & 0.009 & & \\
\hline
\end{tabular}

df: Degree of freedom, MC: Mean square, F: ratio of variances, $p: p$-value.

Table 2. Variance analysis for germination rate index of Medicago ciliaris and Medicago polymorpha populations.

\begin{tabular}{|c|c|c|c|c|c|c|c|c|}
\hline \multirow[b]{2}{*}{$\begin{array}{l}\text { Source of } \\
\text { variation }\end{array}$} & \multicolumn{4}{|c|}{ Medicago ciliaris } & \multicolumn{4}{|c|}{ Medicago polymorpha } \\
\hline & $d f$ & $M C$ & $\mathrm{~F}$ & $p$ & $d f$ & $M C$ & $F$ & $\mathrm{p}$ \\
\hline $\mathrm{NaCl}$ & 3 & 1.188 & 739.030 & 0.000 & 3 & 0.873 & 382.456 & 0.000 \\
\hline$P O P$ & 3 & 0.065 & 40.749 & 0.000 & 3 & 0.0348 & 15.279 & 0.000 \\
\hline $\begin{array}{l}\mathrm{NaCl} x \\
P O P\end{array}$ & 9 & 0.020 & 12.797 & 0.000 & 9 & 0.0064 & 2.832 & 0.014 \\
\hline Error & 32 & 0.001 & & & 32 & 0.0022 & & \\
\hline
\end{tabular}

df: Degree of freedom, MC: Mean square , F: ratio of variances, $p: p$-value. 


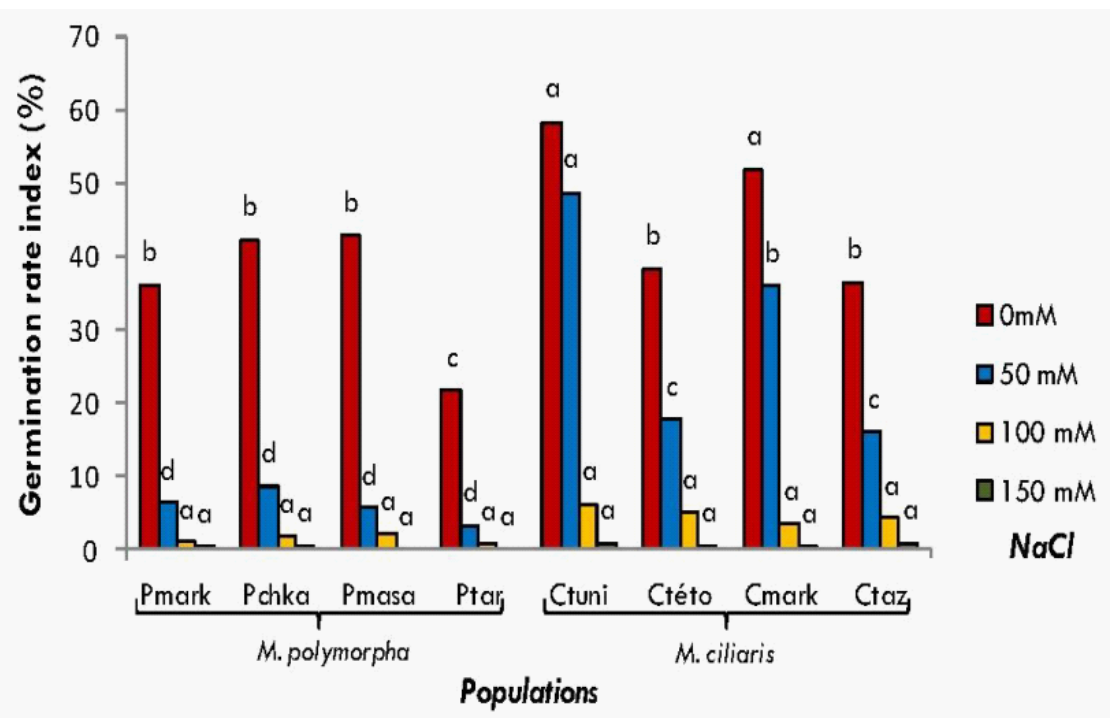

Figure 1. Germination rate index of Medicago ciliaris and Medicago polymorpha in various $\mathrm{NaCl}$ concentrations. At each concentration of $\mathrm{NaCl}$, means of populations having the same letter are not significantly different $(p<0.05)$ (Newman-Keuls test).

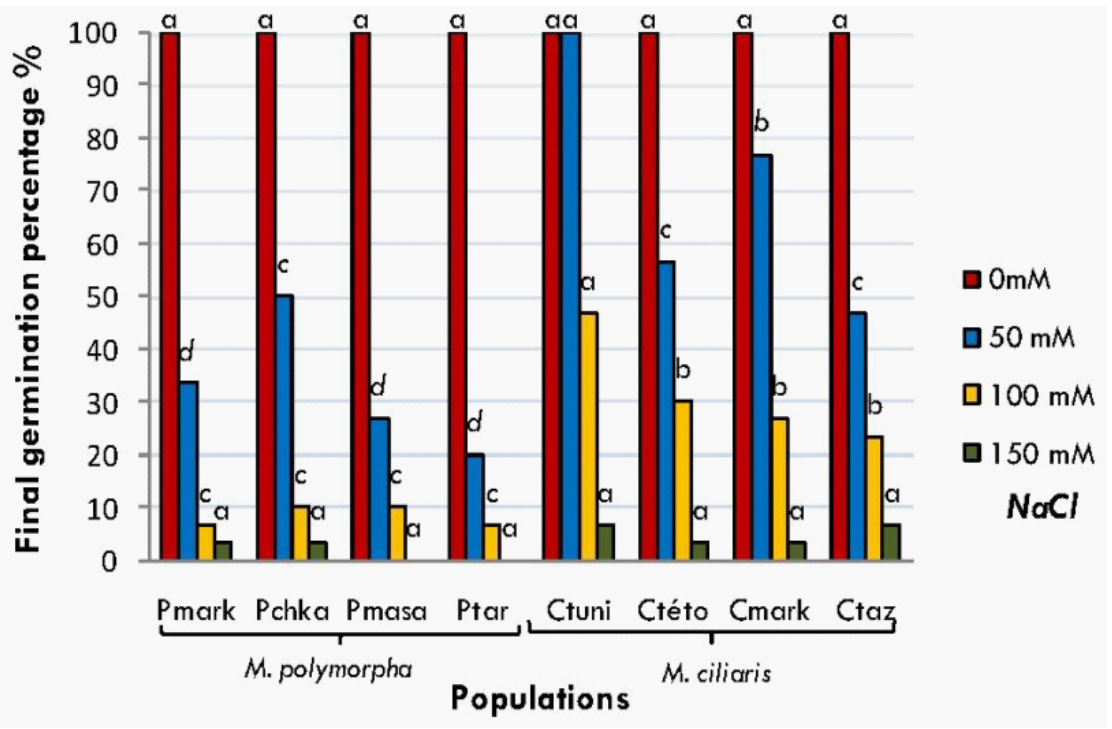

Figure 2. Final germination percentage of Medicago ciliaris and Medicago polymorpha in various $\mathrm{NaCl}$ concentrations. At each concentration of $\mathrm{NaCl}$, means of populations having the same letter are not significantly different $(p<0.05)$ (Newman-Keuls test).

tolerant genotypes in all ecotypes studied in this work with FGP equal to $47 \%$. This ecotype exhibits a particular adaptability to salt environment, at least at this stage in the life cycle.

High salt levels (150 mM) sharply reduced seed germination. At this $\mathrm{NaCl}$ concentration, all populations of the tow species seem to be affected in the same manner, their final germination percentage does not exceed $6.67 \%$ and time to germinate gradually lengthened ( $\mathrm{FGI}<0.85 \%$ ).

This intra-specific variation in salinity tolerance in the two species, also reported in (Chérifi et al., 1993; Ibrar and Hussein,
2003; Rabhi et al., 2007; Nichols et al., 2009), may be used to select genotypes particularly suitable for cultivation on lands relatively affected by salinity; all the more since $M$. ciliaris and M. polymorpha are predominantly autogamous (Chérifi et al., 1993; Mizukami et al., 2006).

\section{Recovery of Germination}

When ungerminated seeds from $\mathrm{NaCl}$ treatments were transferred to distilled water, they recovered largely their germi- 
Ptar

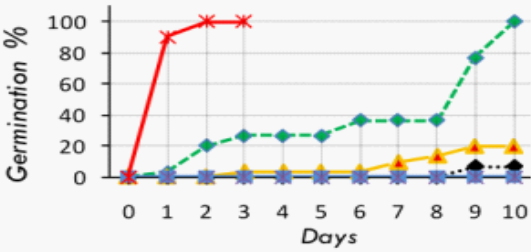

Pmasa

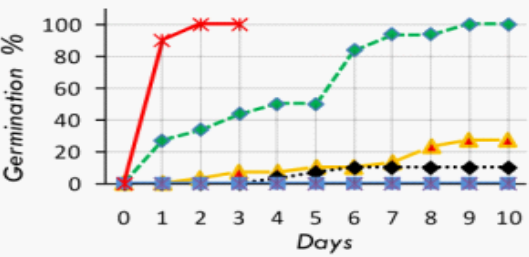

Ctuni

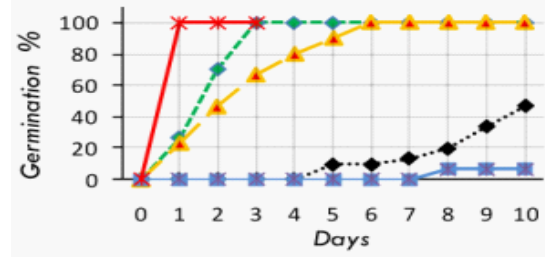

Ctaz

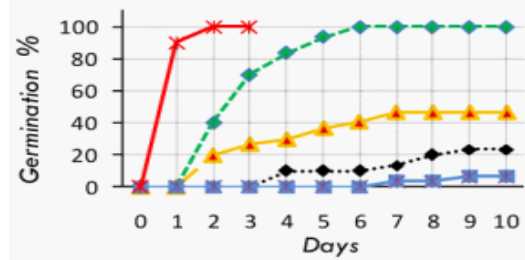

Pchka

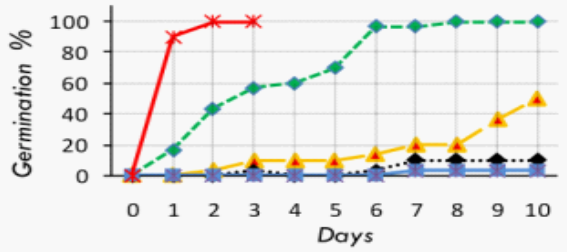

Pmark

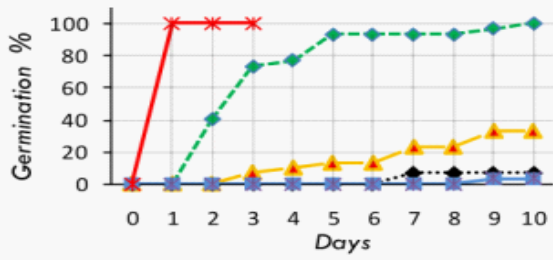

Ctéto

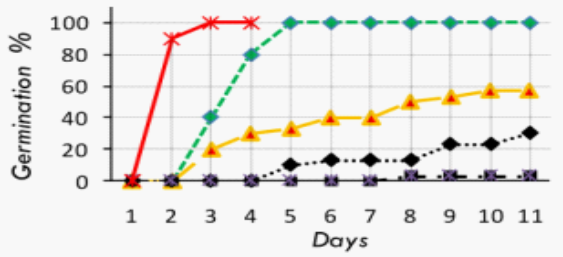

Cmark

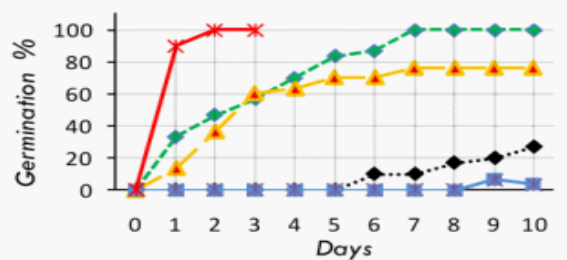

$\rightarrow-0 \mathrm{mM}$

$-1-50 \mathrm{mM}$

$\cdots \leftrightarrow \cdots 100 \mathrm{mM}$

$\longrightarrow-150 \mathrm{mM}$

$\longrightarrow$ Recovery

Figure 3. Cumulative germination percentages of different populations of Medicago ciliaris and Medicago polymorpha showing response both to varied salinity and to germination recovery.

nation at all the populations studied after only 2 days (Fig. 3). These observations indicated that $\mathrm{NaCl}$ caused a greatest osmotic effect on seed germination among the three chloride salt concentrations used in this research. In addition, seed germination in all populations tended to be extremely rapid than that observed in distilled water. This proved to be interesting because it improves the percentage and time of germination compared to the normal conditions. It seems that this pretreatment raises dormancy, which may be necessary in the case of populations with difficult germination like Ptar, Pchka, Pmasa and Cmark populations.

Recovery germination response has been demonstrated in several species including Salsola affinis (Wei et al., 2008), Medicago ruthenica (Guan et al., 2009), Spartina alterniflora (Li et al., 2010) and Diplotaxis harra (Tlig et al., 2008).

Our results, demonstrate that the recovery of germination is not a criterion of salt tolerance which distinguishes halophytes from glycophytes as reported previously (Khan and Ungar, 1984). It was probably due to a reversible osmotic effect that induced dormancy. According to El-Keblawy and Al-Shamsi (2008) a high proportion of seeds remained practical and maintain the ability to germinate when salinity stress was removed. The reduction in germination is therefore attributed to the increased osmotic pressure environment preventing the seed imbibitions (Katembe et al., 1998) and mobilization of reserves for embryo's growth (Prisco and Filho, 1981). Thus, dormancy decrease the risk of seedling mortality when moisture is limited and salinity is augmented (El-Keblawy and Al-Rawai, 2005). High recovery germination speed revealed in the tow species, indicates seeds relative ability to avoid deterioration caused by prolonged exposure to unfavorable biotic factors (Grabe, 1976).

This situation constitutes an ecophysiological adaptive strategy to take advantage of favorable conditions, available for a short time, during the germination stage (Khan and Qaiser, 2006). It also, secure the long-term existence of seed bank helping the species in spreading germination over years (El-Keblawy and Al-Rawai, 2005), especially since the annual species 
of Medicago have the ability to self-regenerate by a large number of seeds production having a staggered germination (Small and Jomphe, 1988; Cocks, 1995). Sowing in the late autumn and early winter would be recommended, to increase the probability of successful plant establishment in rehabilitation program of degraded lands, when salinity and temperature stresses are reduced after the first rains of the season (Guma et al., 2010).

\section{References}

Abdelly C, Z Barhoumi, T Ghnaya, A Debez, K Ben Hamed, R Ksouri, O Talbi, F Zribi, Z Ouerghi and A Smaoui (2006) Potential utilization of halophytes for the rehabilitation and valorization of salt-affected areas in Tunisia. Biosaline Agriculture and Salinity Tolerance in Plants 3: 163-172.

Abdelly C, M Lachaal and C Grignon (1995) Association épisodique d'halophytes stricts et de glycophytes dans un écosystème hydromorphe salé en zone semi-aride. Agronomie 15: 557-568.

Al-Khateeb SA (2006) Effect of salinity and temperature on germination, growth and ion relations of Panicum turgidum Forssk. 97(2): 292-298.

Al-Khatib M, T McNeilly and JC Collins (1992) The potential of selection and breeding for improved salt tolerance in lucerne (Medicago sativa L.). Euphytica 65(1): 43-51.

Ali Z, A Salam, F Azhar and I Khan (2007) Genotypic variation in salinity tolerance among spring and winter wheat (Triticum aestivum L.) accessions. South African Journal of Botany 73(1): 70-75.

Alonso SI, IR Guma and AM Clausen (1999) Variability for salt tolerance during germination in Lolium multiflorum Lam. naturalized in the pampean grasslands. Genet. resour. crop evol. 46(1): 87-94.

Ashraf M and MR Foolad (2007) Roles of glycine betaine and proline in improving plant abiotic stress resistance. Environmental and Experimental Botany 59(2): 206-216.

Baiji MK, J.-M. and S Lutts (2002) Osmotic and ionic effects of $\mathrm{NaCl}$ on germination, early seedling growth, and ion content of Atriplex halimus (Chenopodiaceae). Can. J. Bot. 80: 297-304.

Barrett-Lennard E and T Setter (2010) Developing saline agriculture: moving from traits and genes to systems. Functional Plant Biology 37(7): 3-4.

Ben Naceur M, C Rahmoune, H Sdiri, M-L Meddahi and M Selmi (2001) Effet du stress salin sur la germination, la croissance et la reproduction en grains de quelques variétés maghrébines de blé. Science et changements planétaires / Séchresse 12(3): 167-174.

Chaudhary MT, SJ Wainwright and MJ Merrett (1996) Comparative $\mathrm{NaCl}$ tolerance of Lucerne plants regenerated from salt-selected suspension cultures. Plant Science 114(2): 221-232.

Chérifi K, M Boussaïd and M Marrakchi (1993) Diversité génétique de quelques populations naturelles de Medicago ciliaris (L.) Krock et Medicago intertexta (L.) Mill. I- Analyse de la variabilité morphologique. Agronomie 13: 895-908.

Choukr-allah R (1991) The use of halophytes for the agricultural development of the southern part of Morocco. Plant Salinity Research New Challenges, IAV Hassan II, Agadir, Morocco: pp. 377-386.

Cocks PS (1995) Genotype site interactions in seed production, hard seed breakdown and regeneration of annual medics (Medicago spp.) In west asia. J. Agric. Sci. 125: 199-209.

Correia P, F Gama, M Pestana and M Martins-Loução (2010) Tolerance of young (Ceratonia siliqua L.) carob rootstock to $\mathrm{NaCl}$. Agricultural Water Management 97(6): 910-916.

Dai J, D Huff and M Schlossberg (2009) Salinity effects on seed germination and vegetative growth of greens-type Poa annua relative to other cool-season turfgrass species. Crop science 49.

Duan D, X Liu, MA Khan and B Gul (2004) Effects of salt and water stress on the germination of Chenopodium glaucum L. seed. Pak. J. Bot 36(4): 793-800.

El-Keblawy A and A Al-Rawai (2005) Effects of salinity, temperature and light on germination of invasive Prosopis juliflora (Sw.) DC. Journal of Arid Environments 61(4): 555-565.

El-Keblawy A and N Al-Shamsi (2008) Salinity, temperature and light affect seed germination of Haloxylon salicornicum, a common perennial shrub of the Arabian deserts. Seed Science and Technology 36(3): 679-688.

Esechie HA (1994) Interaction of salinity and temperature on the germination of sorghum. Journal of Agronomy and Crop Science 172(3): 194-199.

Flowers TJ (2004) Improving crop salt tolerance. Journal of Experimental Botany 55(396): 307-319.

Foolad MR (1999) Comparison of salt tolerance during seed germination and vegetative growth in tomato by QTL mapping. Génome 42: 727-734.

Ghoulam C, A Foursy and K Fares (2001) Effect of salinity on seed germination and early seedling growth of sugar beet (Beta vulgaris L.). Seed Sci. And Technol. 29: 357-364.

Gorai M and M Neffati (2007) Germination responses of Reaumuria vermiculata to salinity and temperature. 151(1): 53-59.

Grabe D (1976) Measurement of seed vigor. Journal of Seed Technology, Springfield 1(2): 18-31.

Guma IR, MA Padrón-Mederos, A Santos-Guerra and JA Reyes-Betancort (2010) Effect of temperature and salinity on germination of Salsola vermiculata L. (Chenopodiaceae) from Canary Islands. Journal of Arid Environments 74(6): 708-711.

Hamrouni L, FB Abdallah, C Abdelly and A Ghorbel (2008) La culture in vitro : un moyen rapide et efficace pour sélectionner des génotypes de vigne tolérant la salinité. Comptes Rendus Biologies 331 (2): 152163.

Hussain N, G Sarwar, H Schmeisky, S Al-Rawahy and M Ahmad (2010) Salinity and Drought Management in Legume Crops. Climate Change and Management of Cool Season Grain Legume Crops. In: S S Yadar and Redden R, Springer Netherlands: 171-191.

Ibrar M and F Hussein (2003) The effect of salinity on the growth of Medicago polymorpha Linn. Journal of Science and Technology 27: 35-38.

Itamar V and DJ Ray (1988) Germination of Guar seed under salt temperature stress. J. Amer. Soc. Hort. Sci. $113((3)):$ 437-440.

Katembe WJ, IA Ungar and JP Mitchell (1998) Effect of salinity on germination and seedling growth of tow Atriplex species (Chenopodiaceae). Ann. Bot. 82: 167-175.

Khan M and M Qaiser (2006) Halophytes of Pakistan: characteristics, distribution and potential economic usages. Sabkha Ecosystems 42: 129-153.

Khan $M$ and I Ungar (1984) The effect of salinity and temperature on the germination of polymorphic seeds and growth of Atriplex triangularis Willd. American Journal of Botany 71(4): 481-489.

Khedr AHA, MA Abbas, AAA Wahid, WP Quick and GM Abogadallah (2003) Proline induces the expression of salt-stress-responsive proteins and may improve the adaptation of Pancratium maritimum L. to salt-stress. 54(392): 2553-2562.

Kinet JM, F Benrebiha, S Bouzid, S Lailhacar and P Dutuit (1998) Le réseau Atriplex. Allier biotechnologies et écologie pour une sécurité alimentaire accrue en régions arides et semi-arides. Cahiers Agricultures 7(6): 505-509.

Lahmar R and A Ruellan (2007) Dégradation des sols et stratégies coopératives en Méditerranée: la pression sur les ressources naturelles et les stratégies de développement durable. Cahiers Agricultures 
16(4): $318-323$

Le Houérou HN (1986) Salt tolerance plants of economic value in mediterranean bassin. Reclamation and vegetation research 5: 319-341.

Levigneron A, F Lopez and G Vansuyt (1995) Plants facing salt stress. Cahiers Agricultures 4: 263-273.

Malcolm CV, VA Lindley, JW O'Leary, HV Runciman and EG BarrettLennard (2003) Halophyte and glycophyte salt tolerance at germination and the establishment of halophyte shrubs in saline environments. Plant soil 253(1): 171-185.

Mensah JK, PA Akomeah, B lkhajiagbe and EO Ekpekurede (2006) Effects of salinity on germination, growth and yield of five groundnut genotypes. 5(20): 1973-1979.

Merabet C, A Bekki, N Benrabah, M Bey, L Bouchentouf, H Ameziane, M Rezki, O Domergue, J Cleyet-Marel and J Avarre (2006) Distribution of Medicago species and their microsymbionts in a saline region of Algeria. Arid Land Research and Management 20(3): 219-231.

Mezni M, A Albouchi, E Bizid and M Hamza (2002) Effet de la salinite des eaux d'irrigation sur la nutrition minerale chez trois varietes de luzerne perenne (Medicago sativa). Agronomie 22(3): 283-291.

Mizukami Y, M kato, T Takamizo, M Kanbe, $S$ Inami and $K$ Hattori (2006) Interspecific hybrids between Medicago sativa L. and annual Medicago containing Alfafa weevil resistance. Plant Cell, Tissue and Organ Culture 84(1): 80-89.

Nichols P, A Malik, M Stockdale and T Colmer (2009) Salt tolerance and avoidance mechanisms at germination of annual pasture legumes: importance for adaptation to saline environments. Plant and Soil 315(1): 241-255.

Prisco JT and G Filho (1981) Effect of $\mathrm{NaCl}$ salinity on cotyledon starch mobilization during germination of Vigna anguilata Walp. Seed. Rev Brazil, Bot. 4: 63-71.

Rabhi M, Z Barhoumi, R Ksouri, C Abdelly and M Gharsalli (2007) Interactive effects of salinity and iron deficiency in Medicago ciliaris. Comptes Rendus Biologies 330(1 1): 779-788.

Raccuia SA, V Cavallaro and GM Melilli (2004) Intraspecific variabil- ity in Cynara cardunculus L. var. sylvestris Lam. Sicilian populations: seed germination under salt and moisture stresses. Journal of Arid Environments 56(1): 107-116.

Rogers ME, TD Colmer, K Frost, D Henry, D Cornwall, E Hulm, J Deretic, SR Hughes and AD Craig (2008) Diversity in the genus Melilotus for tolerance to salinity and waterlogging. Plant and Soil 304(1): 89-101.

Shannon MC (1985) Principales and strategies in breeding for higher salt tolerance. Plant Soil 89: 227-241.

Sibole JV, C Cabot, C Poschenrieder and J Barceló (2003) lon allocation in two different salt-tolerant Mediterranean Medicago species. Journal of Plant Physiology 160(11): 1361-1365.

Small E and M Jomphe (1988) A synopsis of the genus Medicago (Leguminosae). Can. J. Bot. 67: 3260-3294.

Song J, G Feng, C Tian and F Zhang (2005) Strategies for adaptation of Suaeda physophora, Haloxylon ammodendron and Haloxylon persicum to a saline environment during seed-germination stage. Annals of Botany 96(3): 399.

StatSoft Inc (2001) STATISTICA (data analysis software system), version 6. Tulsa, USA.

Turkington R, E John, S Watson and P Seccombe Hett (2002) The effects of fertilization and herbivory on the herbaceous vegetation of the boreal forest in north western Canada: a 10 year study. Journal of Ecology 90(2): 325-337.

Vinocur B and A Altman (2005) Recent advances in engineering plant tolerance to abiotic stress: achievements and limitations. Current Opinion in Biotechnology 16(2): 123-132.

Weng JH and FH Hsu (2006) Variation of Germination Response to Temperature in Formosan Lily (Lilium formosanum Wall.) Collected from Different Latitudes and Elevations in Taiwan. Plant Production Science 9(3): 281-286.

Yamaguchi T and E Blumwald (2005) Developing salt-tolerant crop plants: challenges and opportunities. 10(12): 615-620. 